\title{
Regulation of Endothelial Cell Cyclic Nucleotide Metabolism by Prostacyclin
}

\author{
NANCy K. Hopkins and Robert R. GoRman, Experimental Biology, The Upjohn \\ Company, Kalamazoo, Michigan 49001
}

A B S T RACT An analysis of prostaglandin-stimulated adenosine $3^{\prime}, 5^{\prime}$-cyclic monophosphate (cyclic AMP) accumulation in cultured human umbilical vein endothelial cells showed prostacyclin $\left(\mathrm{PGI}_{2}\right)$ to be the most potent agonist followed by prostaglandin $(\mathrm{PG}) \mathrm{H}_{2}$, which was more potent than $\mathrm{PGE}_{2}$, while $\mathrm{PGD}_{2}$ was essentially inactive.

The endothelial cells studied apparently have a high rate of cyclic AMP phosphodiesterase activity because significant $\mathrm{PGI}_{2}$-mediated increases in cyclic AMP could only be shown in the presence of the phosphodiesterase inhibitor isobutylmethylxanthine (MIX).

Endoperoxide $\mathrm{PGH}_{2}$-stimulation of cyclic AMP accumulation was inhibited $75-80 \%$ by the prostacyclin synthetase inhibitors 12-hydroperoxyeicosatetraenoic acid or 9,11-azoprosta-5,13-dienoic acid. These data indicate that the $\mathrm{PGH}_{2}$-stimulation is due primarily to conversion to $\mathrm{PGI}_{2}$.

The beta-adrenergic agonist L-isoproterenol stimulated cyclic AMP accumulation in the endothelial cells. This accumulation was completely blocked by propranolol. However, stimulation of cyclic AMP accumulation by the beta-adrenergic agent did not equal that induced by $\mathrm{PGI}_{2}$. Furthermore, the $\mathrm{PGI}_{2}$ response could not be blocked by propranolol.

Thrombin-stimulated $\mathrm{PGI}_{2}$ biosynthesis was attenuated by $\mathrm{PGE}_{1}$ or isoproterenol in the presence of MIX. MIX alone was less effective than a combination of $\mathrm{PGE}_{1}$ or isoproterenol plus MIX.

These data suggest two potential effects of $\mathrm{PGI}_{2}$ biosynthesis by endothelial cells: first, the $\mathrm{PGI}_{2}$ can elevate cyclic AMP in platelets, and second, endothelial cell cyclic AMP can be elevated as well, so that subsequent $\mathrm{PGI}_{2}$ synthesis will be attenuated.

\section{INTRODUCTION}

Prostacyclin [(5Z)-9-deoxy-6,9- $\alpha$-epoxy- $\Delta^{5}$-prostaglandin $\left.\mathrm{F}_{1 \alpha}\right]\left(\mathrm{PGI}_{2}\right)^{1}$ is a labile prostaglandin that is a

Received for publication 13 June 1980 and in revised form 16 October 1980.

${ }^{1}$ Abbreviations used in this paper: azo analog I, 9,11-azoprosta-5, 13-dienoic acid; 12-HPETE, 12-hydroperoxyeicos- potent vasodilator and the most powerful inhibitor of human platelet aggregation yet described (1-4). Vascular tissue and especially vascular endothelium are rich sources of $\mathrm{PGI}_{2}$ synthetase activity (5-7), and the relationship(s) between the synthesis of the antiaggregatory $\mathrm{PGI}_{2}$ by vascular elements and the synthesis of the proaggregatory molecule thromboxane $A_{2}$ by platelets have been widely discussed $(3,4,8,9)$.

$\mathrm{PGI}_{2}$ is a potent stimulator of platelet adenylate cyclase $(3,4)$, and elevates cyclic AMP levels in cultured human foreskin fibroblasts (10), human fat cell ghosts (11), and several clonal cell lines of central nervous system origin (12). $\mathrm{PGI}_{2}$ also elevates cyclic AMP levels in arterial rings (13), but no experiments on the effect of $\mathrm{PGI}_{2}$ on cyclic AMP levels in endothelial cells have been reported to date.

In the present study we show that $\mathrm{PGI}_{2}$ is a potent stimulator of cultured human umbilical vein endothelial cell cyclic AMP levels, and suggest that endogenously produced $\mathrm{PGI}_{2}$ may regulate subsequent $\mathrm{PGI}_{2}$ biosynthesis by stimulating adenylate cyclase.

\section{METHODS}

Materials. Prostaglandins (PG) $\mathrm{I}_{2}, \mathrm{E}_{1}, \mathrm{E}_{2}, \mathrm{D}_{2}$, and the prostaglandin analog 9,11 azoprosta-5,13-dienoic acid (azo analog I) were obtained from The Upjohn Company, Kalamazoo, Mich. $\mathrm{PGH}_{2}$ and 12-hydroperoxyeicosatetraenoic acid (12-HPETE) were biosynthesized according to Gorman et al. (14) and Nugteren et al. (15). [ $\left.\alpha{ }^{-32} \mathrm{P}\right]$ ATP $(10-30 \mathrm{Ci} /$ mmol) was purchased from ICN Pharmaceuticals, Irvine, Calif., and $\left[{ }^{3} \mathrm{H}\right]$ cyclic AMP was obtained from Schwarz/Mann Div., Becton, Dickinson \& Co., Orangeburg, N. Y. $\left[{ }^{3} \mathrm{H}\right] 6$ Keto-PGF ${ }_{1 \alpha}$ was purchased from New England Nuclear, Boston, Mass. Dowex AG 50W-4X was purchased from Bio-Rad Laboratories, Richmond, Calif. Type I collagenase was purchased from Worthington Biochemical Corp., Freehold, N. J. $\left[{ }^{125} \mathrm{I}\right]-2^{\prime} O$-Succinyl cyclic AMP tyrosine methyl ester and cyclic AMP antiserum were purchased from Collaborative Research Inc., Waltham, Mass. Isobutylmethylxanthine (MIX) was purchased from Aldrich Chemical Co., Milwaukee, Wis.

atetraenoic acid; MEM, minimal essential medium; MIX, isobutylmethylxanthine; $\mathrm{PG}$, prostaglandin; $\mathrm{PGI}_{2}$, prostacyclin. 
L-Isoproterenol hydrochloride, D,L-propranolol hydrochloride, thrombin $(3,000 \mathrm{U} / \mathrm{ml})$ and ristocetin were purchased from Sigma Chemical Co., St. Louis, Mo. Human Factor VIII antiserum was purchased from CalbiochemBehring Corp., American Hoechst Corp., San Diego, Calif., and the fluorescein conjugated goat anti-rabbit antiserum was obtained from N. L. Cappel Laboratories Inc., Cochranville, $\mathrm{Pa}$. Plastic tissue culture flasks and plates were from Falcon Plastics, Labware, Div. of Becton, Dickinson \& Co., Oxnard, Calif. and Costar, Data Packaging, Cambridge, Mass.

Medium 199 with Earle's salts and L-glutamine as well as Hepes buffer were purchased from Microbiological Associates, Walkersville, Md.

The medium 199 was supplemented with sterile filtered human serum to a volume of $20 \%$ serum, Hepes buffer $(15 \mathrm{~m} . \mathrm{I}$, $\mathrm{pH}$ 7.5), L-glutamine $(2 \mathrm{m.M})$, sodium penicillin $\mathrm{G}(100$ $\mathrm{U} / \mathrm{ml}$, The Upjohn $\mathrm{C}_{0}$.) and streptomycin sulfate $(100 \mu \mathrm{g} / \mathrm{ml}$, Eli Lilly Co., Indianapolis, Ind.). Sterile saline and distilled water were purchased from Abbott Diagnostics, Chicago, Ill.

Radioimmunoassay of cyclic A.MP. Cyclic AMP was measured in confluent endothelial cell monolayers $\sim 0.8 \times 10^{6}$ cells $/ 35-\mathrm{mm}$ well. Each well was washed once with $2.0 \mathrm{ml}$ of warmed minimal essential medium (MEM) containing $25 \mathrm{mM}$ Hepes buffer (no serum or phenol indicator). The cells were allowed to equilibrate with $1.0 \mathrm{ml}$ of MEM-Hepes containing $1.0 \mathrm{mM}$ MIX for $10 \mathrm{~min}$ before the addition of agonists. The reactions were terminated by the addition of $0.5 \mathrm{ml}$ of $10 \%$ trichloroacetic acid, and the aqueous samples extracted three times with $10 \mathrm{vol}$ of diethylether. Cyclic AMP was measured by radioimmunoassay according to Steiner et al. (16) with the incorporation of the acetylation modification of Harper and Brooker (17). All samples were tested at two dilutions. Data are presented as the mean $\pm S E M$ of triplicate determinations.

Radioimmunoassay of 6-keto PGF $F_{1 \alpha}$. Thombin-stimulated $\mathrm{PGI}_{2}$ biosynthesis was studied by measuring 6-keto$\mathrm{PGF}_{1 \alpha}$ by radioimmunoassay according to Dray et al. (18). The antiserum was a gift from Dr. Fernando Dray, The Pasteur Institute, Paris, France. All samples were assayed at two dilutions. Data are presented as mean \pm SEM of triplicate determinations.

Endothelial cell monolayers were washed once with $2.0 \mathrm{ml}$ of MEM-Hepes buffer and allowed to equilibrate with an additional $1.0 \mathrm{ml}$ of $\mathrm{MEM}$-Hepes for $10 \mathrm{~min}$ at $37^{\circ} \mathrm{C}$. After the equilibration period, the cells were challenged with $2.0 \mathrm{U}$ of thrombin, and allowed to incubate for an additional $10 \mathrm{~min}$ at $37^{\circ} \mathrm{C}$. The media was then immediately withdrawn and frozen in liquid $\mathrm{N}_{2}$, and aliquots of the samples were analyzed for 6-keto-PGF ${ }_{1 \alpha}$.

In experiments where $\mathrm{PGE}_{1}$ was used to stimulate cyclic AMP levels, all of the samples and standards were assaved before and after alkali treatment. This was done to dehydrate $\mathrm{PGE}_{1}$ to $\mathrm{PGA}_{1}$ and eliminate $\mathrm{PGE}_{1}$ crossreaction with the 6keto-PGF $F_{1 \alpha}$ antiserum. Base treatment was done by adjusting the samples to $\mathrm{pH} 10.0$ with $\mathrm{NaHCO}_{3}$, followed by boiling to dryness. The dried samples were reconstituted with $\mathrm{H}_{2} \mathrm{O}$ and the $\mathrm{pH}$ readjusted to 7.4 for subsequent radioimmunoassay. Authentic 6 -keto- $\mathrm{PGF}_{1 \alpha}$ was degraded $<5 \%$ by this procedure, whereas $\mathrm{PGE}_{1}$ was essentially completely dehydrated to $\mathrm{PGA}_{1}$.

Preparation of particulate fraction for adenylate cyclase assay. To eliminate $\mathrm{PGI}_{2}$ biosynthesis during processing particulate fractions were prepared from endothelial cells pretreated for $1 \mathrm{~h}$ with $1 \mathrm{mM}$ acetylsalicyclic acid. Previous experience has shown that this treatment inhibits at least $95 \%$ of the thrombin-stimulated $\mathrm{PGI}_{2}$ biosynthesis. Cells were harvested with a rubber spatula, and the pooled cells centrifuged at $4^{\circ} \mathrm{C}$ for $15 \mathrm{~min}$ at $2,000 \times \mathrm{g}$. The cell pellet was resuspended in cold $50 \mathrm{mM}$ Tris- $\mathrm{HCl}, 0.15 \mathrm{M} \mathrm{NaCl}$ buffer, $\mathrm{pH}$
7.50, and frozen and thawed three times in liquid $N_{2}$, followed by 10 strokes of a Dounce homogenizer (Kontes Co., Vineland, N. J.) (glass/glass). The homogenate was then centrifuged at $10,000 \times \mathrm{g}$ for $15 \mathrm{~min}$ at $4^{\circ} \mathrm{C}$. The resulting pellet was then resuspended in $1 \mathrm{m.M} \mathrm{KHCO}_{3}$ and used directly in the adenylate cyclase assay.

Adenylate cyclase activity was measured according to Rodbell (19) with modifications as reported by Salomon et al. (20), from the rate of formation of cyclic AMP from $\left[\alpha-{ }^{32} \mathrm{P}\right]$ ATP. All incubations contained $10 \mathrm{~m} . \mathrm{M}$ theophylline. Data are presented as picomoles cyclic AMP per 10 min per milligram protein determined according to Lowry et al. (21).

Culture and characterization of endothelial cells. Endothelial cells were derived from human umbilical cord veins as described by Jaffe et al. (22). Cords were stored in sterile containers with $20 \mathrm{ml}$ of cord buffer $(137 \mathrm{mM} \mathrm{NaCl}, 4 \mathrm{mM} \mathrm{KCl}$ $10 \mathrm{~m} . \mathrm{M}$ Hepes, $\mathrm{pH} 7.5$, and $11 \mathrm{m.l}$ glucose). A disposable syringe was attached to a blunt needle and the vein was flushed with $50 \mathrm{ml}$ of cord buffer to remove any blood. The vein was then perfused with $10 \mathrm{ml}$ of $0.1 \%$ collagenase in cord buffer, and incubated at $37^{\circ} \mathrm{C}$ in a bath of cord buffer for 10 min. The collagenase-cell mixture was flushed from the vein with $30 \mathrm{ml}$ of buffer into a plastic centrifuge tube that contained $10 \mathrm{ml}$ of medium 199 and centrifuged at $200 \mathrm{~g}$ for $5 \mathrm{~min}$. The cell pellet was resuspended in $10 \mathrm{ml}$ of fresh medium 199 and added to a T-75 flask. Cells were exposed to an atmosphere of $95 \%$ air $-5 \% \mathrm{CO}_{2}$ and were fed twice a week until subculturing. Confluency was usually reached in 4-5 d.

For subculturing the medium was removed and the cells rinsed once with cord buffer. A 5-min incubation with a $1: 1$ mixture of $0.02 \%$ EDTA: $0.2 \%$ collagenase followed by centrifugation was used to harvest the cells. Cells were grown in either T-150 culture flasks or distributed into $35-\mathrm{mm}$ wells.

Endothelial cells were characterized by $(a)$ the presence of Weibel-Palade bodies as observed by electron microscopy (23), (b) the ability of the medium from cultured cells to support ristocetin-induced agglutination of washed human platelets (24), and (c) by immunofluorescence studies of Factor VIII antigen using a rabbit antibody to human Factor VIII, and a fluorescein-conjugated goat anti-rabbit gamma globulin (25).

\section{RESULTS}

Incubation of intact endothelial cell monolayers with $2.8 \mu \mathrm{M} \mathrm{PGI}_{2}$ resulted in a marked increase in cyclic AMP within $1 \mathrm{~min}$. The response was maximal at 10 $\mathrm{min}$, and then gradually declined over the next $50 \mathrm{~min}$ (Fig. 1). Most of the cyclic AMP remained intracellular for at least $60 \mathrm{~min}$ (Fig. 1). We included $1 \mathrm{mM}$ MIX, the cyclic AMP phosphodiesterase inhibitor, in all of our experiments because without MIX there was only a small increase in cyclic AMP in response to $\mathrm{PGI}_{2}$ (Fig. 1).

Dose-response analysis indicated that $\mathrm{PGI}_{2}$ was a more potent stimulator of endothelial cell cyclic AMP levels than either $\mathrm{PGH}_{2}$ or $\mathrm{PGE}_{2}$, whereas $\mathrm{PGD}_{2}$ was essentially inactive (Fig. 2). As little as $28 \mathrm{nM} \mathrm{PGI}_{2}$ significantly elevated cyclic AMP levels above basal levels, and $2.8 \mu \mathrm{M} \mathrm{PGI}_{2}$ gave maximal stimulation (Fig. 2). This dose-response profile was similar to data previously reported in cultured human foreskin fibroblasts (10).

Most of the stimulation of cyclic AMP levels in response to $\mathrm{PGH}_{2}$ was shown to be due to conversion of $\mathrm{PGH}_{2}$ to $\mathrm{PGI}_{2}$ by the endothelial cell monolayers. Incu- 


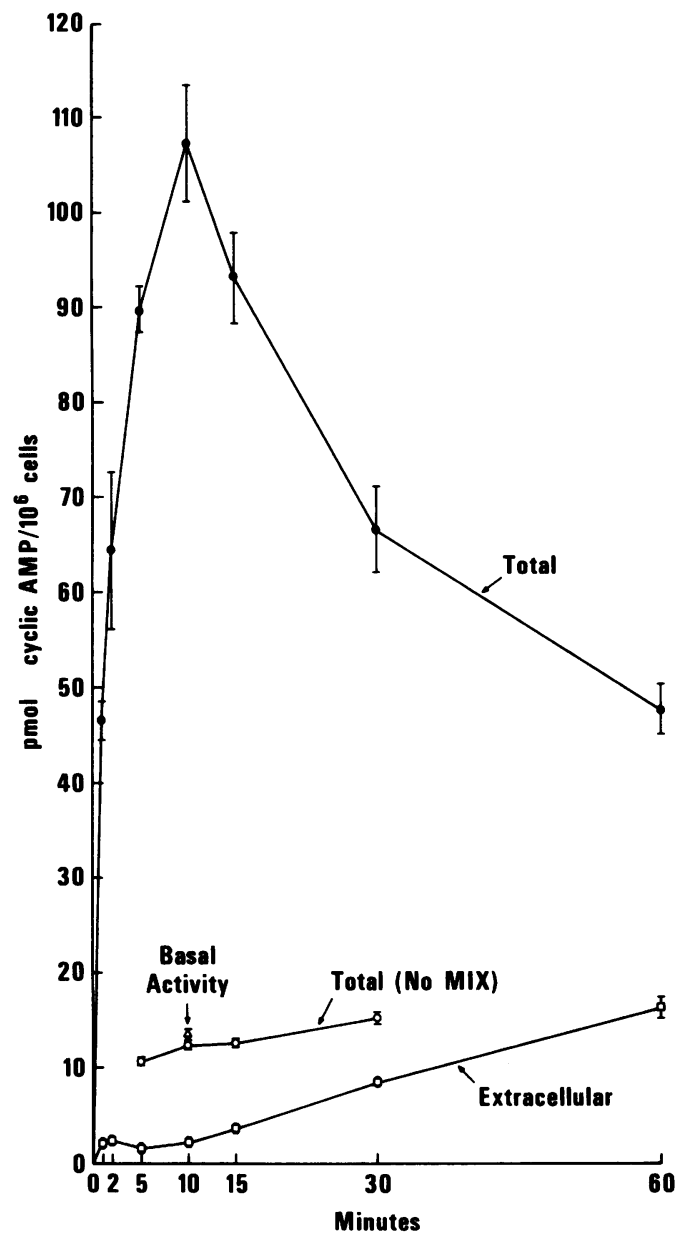

Figure 1 Time-course of total and extracellular cyclic AMP levels in human endothelial cells. Cells were stimulated with $2.8 \mu \mathrm{M} \mathrm{PGI}$ from 1 to $60 \mathrm{~min}$ and both total $(0)$ and extracellular ( $\square$ ) cyclic AMP levels measured in the presence of 1 mM MIX. Other wells of endothelial cells were challenged with the same concentration of $\mathrm{PGI}_{2}$ but without MIX (O) present. Data are presented as mean \pm SEM pmol cyclic AMP/ $10^{6}$ cells of triplicate samples.

bation of endothelial cell monolayers with the $\mathrm{PGI}_{2}$ synthetase inhibitors 12-HPETE $(28 \mu \mathrm{M})$, or azo analog $\mathrm{I}(2.8 \mu \mathrm{M})$ inhibited $\mathrm{PGH}_{2}$-stimulated cyclic AMP levels 75 and $80 \%$, respectively when base-line activity was subtracted (Fig. 3). Neither inhibitor significantly changed the basal level of cyclic AMP (Fig. 3).

As shown previously (26), endothelial cells also have a $\beta$-adrenergic receptor that is coupled to the adenylate cyclase. Our data shows that the maximal $\beta$-adrenergic stimulation of cyclic AMP accumulation by Lisoproterenol is considerably less than the stimulation observed with $2.8 \mu \mathrm{M} \mathrm{PGI}_{2}$ (Fig. 4). The isoproterenolstimulation was completely blocked by $10 \mu \mathrm{M}$ propranolol, but propranolol did not inhibit the $\mathrm{PGI}_{2}-$ stimulation of cyclic AMP levels (Fig. 4).

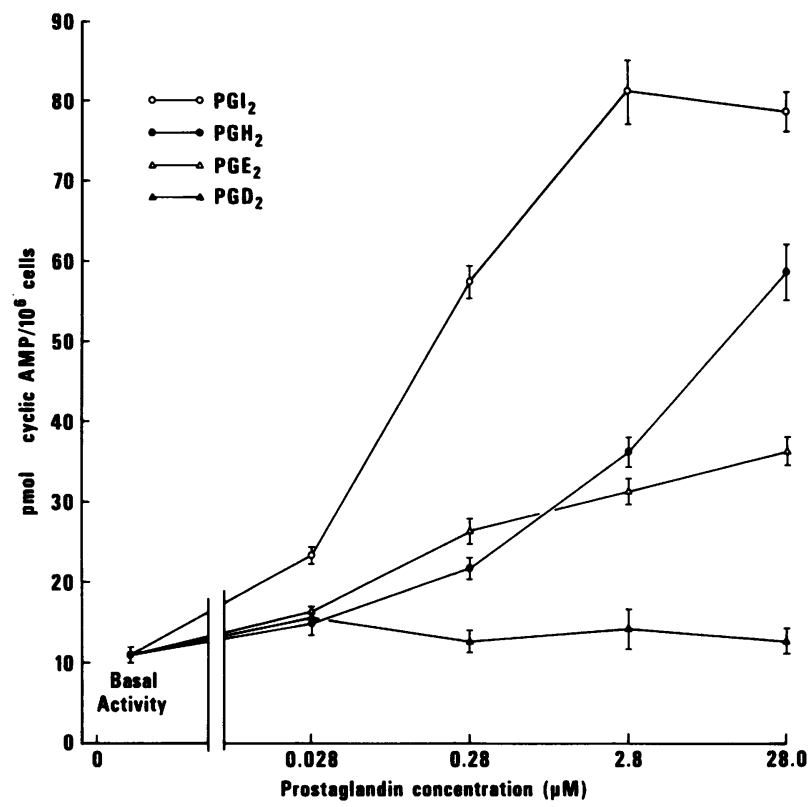

FIgURE 2 Dose-response relationship for prostaglandin stimulation of cyclic AMP. Endothelial cells were incubated for 10 min with $1 \mathrm{mM}$ MIX before challenging with from 28 $\mathrm{nM}$ to $28.0 \mu \mathrm{M} \mathrm{PGI}_{2}, \mathrm{PGH}_{2}, \mathrm{PGE}_{2}$, or $\mathrm{PGD}_{2}$. All prostaglandins were incubated with the cells for $10 \mathrm{~min}$ at $37^{\circ} \mathrm{C}$. Data are presented as mean $\pm \mathrm{SEM}$ pmol cyclic AMP $/ 10^{6}$ cells of triplicate samples.

In contrast, the $\alpha$-adrenergic agonist phenylephrine did not stimulate or inhibit endothelial cell adenylate cyclase (unpublished experiments).

In addition to measuring cyclic AMP in intact endo-

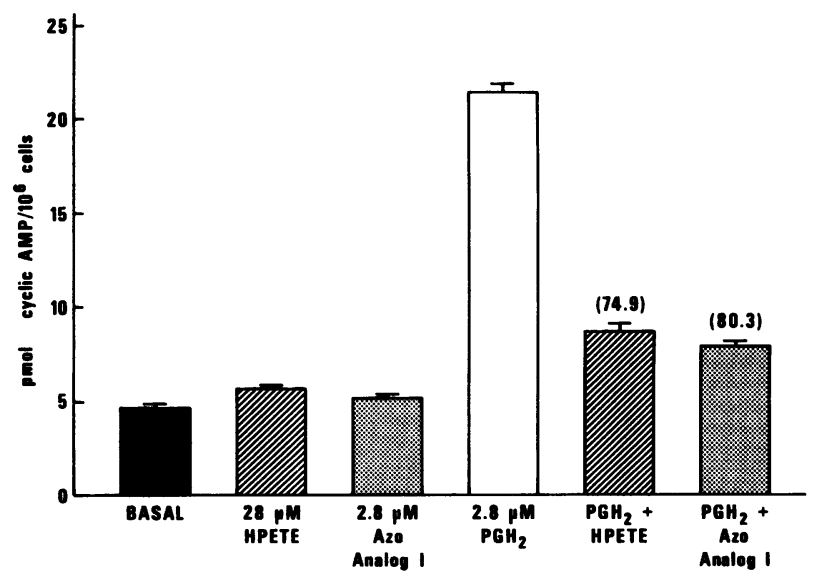

FIgURE 3 Inhibition of $\mathrm{PGH}_{2}$ stimulation of cyclic AMP accumulation by 12-HPETE or azo analog I. Confluent human endothelial cells were preincubated for $10 \mathrm{~min}$ at $37^{\circ} \mathrm{C}$ with $1 \mathrm{mM}$ MIX and with either $28 \mu \mathrm{M}$ 12-HPETE or $2.8 \mu \mathrm{M}$ azo analog I before exposure to $2.8 \mu \mathrm{M} \mathrm{PGH}_{2}$. Numbers in brackets above bar graphs represent percent inhibition of $\mathrm{PGH}_{2}$-stimulated cyclic AMP accumulation when basal levels of cyclic AMP are subtracted. Data reported as mean \pm SEM pmol cyclic AMP $/ 10^{6}$ cells of triplicate samples. 


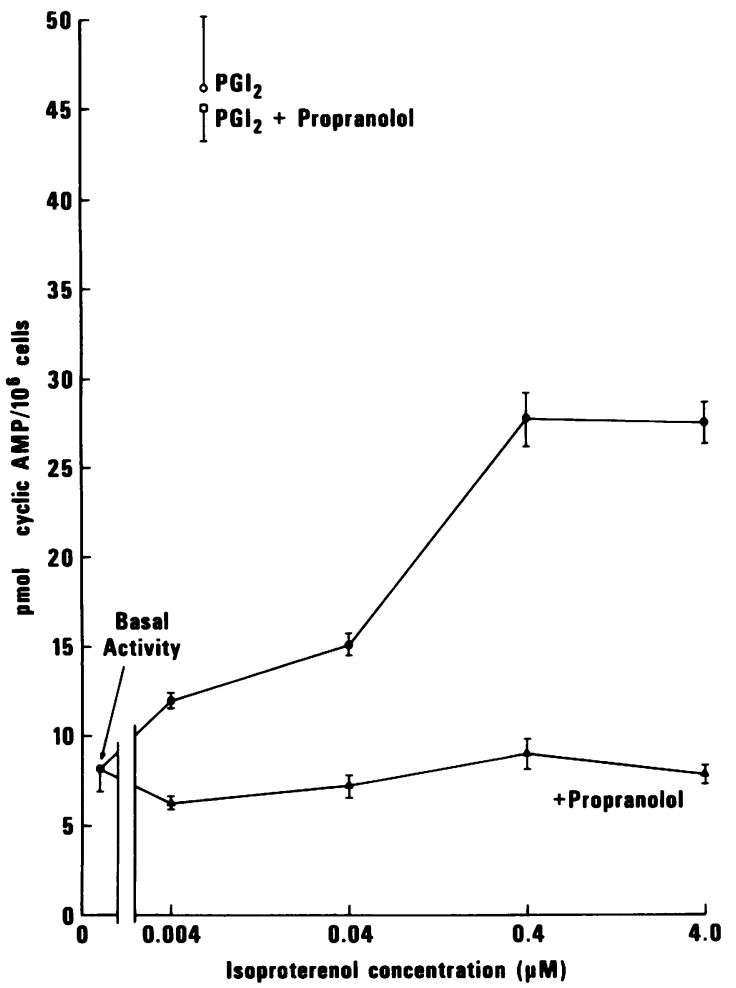

Figure 4 Isoproterenol dose-response curve. Endothelial cells were incubated for $10 \mathrm{~min}$ at $37^{\circ} \mathrm{C}$ with from $4 \mathrm{nM}$ to 4 $\mu \mathrm{M}$ isoproterenol in the presence of $1 \mathrm{mM}$ MIX. Another group of cells were preincubated for $10 \mathrm{~min}$ with MIX plus $33.8 \mu \mathrm{M}$ propranolol before challenging with several concentrations of isoproterenol. Stimulation of cyclic AMP levels by $2.8 \mu \mathrm{M} \mathrm{PGI}_{2}$ was also done with and without propranolol. Data are presented as mean $\pm S E M$ pmol cyclic AMP $/ 10^{6}$ cells of triplicate samples.

thelial cell monolayers, we also measured adenylate cyclase activity in homogenates prepared from endothelial cells. $\mathrm{PGI}_{2}$ and $\mathrm{PGE}_{1}$ gave modest increases in enzyme activity and isoproterenol an even smaller stimulation (Table I). Both $\mathrm{PGD}_{2}$ and adenosine were inactive as stimulators of adenylate cyclase (Table I).

Weksler et al. (27) have shown that thrombin stimulates endothelial cell $\mathrm{PGI}_{2}$ biosynthesis. We have found that thrombin-stimulated $\mathrm{PGI}_{2}$ biosynthesis (as measured by 6 -keto- PGF $_{1 \alpha}$ levels) was attenuated by both $\mathrm{PGE}_{1}$ and L-isoproterenol when the phosphodiesterase was inhibited (Table II). Neither PGE $_{1}$ nor Lisoproterenol inhibited $\mathrm{PGI}_{2}$ biosynthesis in the absence of phosphodiesterase inhibition (Table II). The data presented were obtained before and after base treatment (Methods), because PGE $_{1}$ was used to elevate cyclic AMP levels, and $\mathrm{PGE}_{1}$ cross-reacts with the 6-keto-PGF $1 \alpha$ antibody. Authentic $\mathrm{PGI}_{2}$ could not be used because this would have generated too much exogenous 6-keto-PGF ${ }_{1 \alpha}$, and hampered the subsequent measurement of endogenously synthesized $\mathrm{PGI}_{2}$. Base
TABLE I

Endothelial Cell Adenylate Cyclase Activity

\begin{tabular}{lc}
\hline \multicolumn{1}{c}{ Additions } & Adenylate cyclase activity \\
\hline & pmol cyclic AMP/mg protein \\
None-Basal & $633.6 \pm 44$ \\
$28 \mu \mathrm{M} \mathrm{PGI}$ & $976.5 \pm 74$ \\
$28 \mu \mathrm{M} \mathrm{PGE}$ & $957.9 \pm 66$ \\
$28 \mu \mathrm{M} \mathrm{PGD}$ & $624.6 \pm 32$ \\
$10 \mu \mathrm{M}$ Isoproterenol & $721.1 \pm 38$ \\
$10 \mu \mathrm{M}$ Adenosine & $605.4 \pm 42$
\end{tabular}

A particulate preparation of homogenized endothelial cells (82 $\mu \mathrm{g}$ protein) was incubated for $10 \mathrm{~min}$ at $30^{\circ} \mathrm{C}$ with either $28 \mu \mathrm{M} \mathrm{PGI}_{2}, \mathrm{PGE}_{1}$, or $\mathrm{PGD}_{2}$, or with $10 \mu \mathrm{M}$ isoproterenol or adenosine. Assay conditions and purification of cyclic AMP are described in the Methods. Data are representative of three confirmatory experiments and are presented as the mean \pm SEM of triplicate samples. Membranes prepared in this manner converted $15.4 \%$ of exogenously added $\left[1-{ }^{14} \mathrm{C}^{\mathrm{PGGH}} \mathrm{PG}_{2}\right.$ to 6-keto-PGF $F_{1 \alpha}$ and the synthesis of 6-keto- $\mathrm{PGF}_{1 \alpha}$ was blocked by $2.8 \mu \mathrm{M}$ azo analog I. This rate of conversion is analogous to previously published data in endothelial cells (7).

treatment of samples hydrolyzes $\mathrm{PGE}_{1}$ to $\mathrm{PGA}_{1}$, and $\mathrm{PGA}_{1}$ does not interfere with the measurement of 6-keto-PGF $F_{1 \alpha}$ (18). Authentic 6-keto-PGF ${ }_{1 \alpha}$ is not degraded by base treatment (Table II). Of particular interest was the observation that $1.0 \mathrm{mM}$ MIX alone could also reduce thrombin-stimulated $\mathrm{PGI}_{2}$ biosynthesis (Table II). A combination of $\mathrm{PGE}_{1}$ and $1.0 \mathrm{mM}$ MIX inhibited $\mathrm{PGI}_{2}$ biosynthesis $70.0 \%$ whereas $1.0 \mathrm{mM}$ MIX inhibited synthesis $38 \%$ (Table II).

TABLE II

Inhibition of $\mathrm{PGI}_{2}$ Biosynthesis by $P G E_{1}$ and $\mathrm{L}-$ Isoproterenol

\begin{tabular}{|c|c|c|}
\hline Treatment & $\begin{array}{c}\text { Before base } \\
\text { treatment }\end{array}$ & $\begin{array}{l}\text { After base } \\
\text { treatment }\end{array}$ \\
\hline & \multicolumn{2}{|c|}{ ng 6-Keto-PGF ${ }_{1 \alpha} / 10^{6}$ Cells } \\
\hline None-basal & $1.8 \pm 0.3$ & $1.7 \pm 0.2$ \\
\hline $2 \mathrm{U}$ Thrombin & $18.2 \pm 0.7$ & $18.8 \pm 1.0$ \\
\hline $0.28 \mu \mathrm{M} \mathrm{PGE}_{1}$ & $22.4 \pm 2.0$ & $1.1 \pm 0.1$ \\
\hline Thrombin + PGE $_{1}$ & $51.4 \pm 2.7$ & $21.2 \pm 0.5$ \\
\hline Thrombin $+\mathrm{PGE}_{1}+1.0 \mathrm{mM} \mathrm{MIX}$ & $31.2 \pm 0.7$ & $5.6 \pm 0.3$ \\
\hline $4.0 \mu \mathrm{M}$ Isoproterenol & $1.5 \pm 0.3$ & $1.4 \pm 0.1$ \\
\hline Thrombin + isoproterenol & $18.9 \pm 1.5$ & $18.1 \pm 1.3$ \\
\hline Thrombin + iso + $1.0 \mathrm{mM}$ MIX & $6.1 \pm 0.2$ & $6.2 \pm 0.4$ \\
\hline Thrombin $+1.0 \mathrm{mM}$ MIX & $12.4 \pm 0.4$ & $11.6 \pm 0.6$ \\
\hline
\end{tabular}

Confluent monolayers of endothelial cells in 35-mm wells were washed once with $2.0 \mathrm{ml}$ of warm MEM containing $25 \mathrm{mM}$ Hepes buffer. The cells were allowed to equilibrate with $1.0 \mathrm{ml}$ of MEM-Hepes with or without $\mathrm{PGE}_{1}$, isoproterenol or $1.0 \mathrm{mM}$ MIX for $10 \mathrm{~min}$ at $37^{\circ} \mathrm{C}$. Thrombin was added at the end of the 10-min equilibration period and allowed to incubate for an additional $10 \mathrm{~min}$ with the cells. Data are reported as mean $\pm S E M$ of triplicate samples. 
TABLE III

Elevation of Endothelial Cell Cyclic AMP Levels by $\mathrm{PGI}_{2}$ and Thrombin

\begin{tabular}{ll}
\hline Additions & Cyclic AMP \\
\hline$p m o l / 10^{6}$ cells
\end{tabular}

$\begin{array}{lr}\text { None-basal } & 1.9 \pm 0.2 \\ 0.1 \mathrm{mM} \text { MIX } & 4.6 \pm 0.1 \\ 1.0 \mathrm{mM} \text { MIX } & 8.7 \pm 0.6 \\ 0.28 \mu \mathrm{M} \text { PGI } & 3.4 \pm 0.1 \\ 2 \mathrm{U} \text { Thrombin } & 2.6 \pm 0.2 \\ 0.1 \mathrm{mM} \mathrm{MIX}+\mathrm{PGI}_{2} & 15.2 \pm 0.4 \\ 1.0 \mathrm{mM} \mathrm{MIX}+\mathrm{PGI}_{2} & 64.4 \pm 2.5 \\ 0.1 \mathrm{mM} \mathrm{MIX}+\text { thrombin } & 8.4 \pm 1.2 \\ 1.0 \mathrm{mM} \text { MIX + thrombin } & 22.8 \pm 0.6\end{array}$

Confluent monolayers of endothelial cells in 35-mm wells were washed once with $2.0 \mathrm{ml}$ of warm MEM containing $25 \mathrm{mM}$ Hepes buffer. The cells were then allowed to equilibrate with $1.0 \mathrm{ml}$ of MEM-Hepes buffer with or without 0.1 or $1.0 \mathrm{mM}$ MIX for $10 \mathrm{~min}$ at $37^{\circ} \mathrm{C}$. After the 10 -min equilibration period the cells were exposed to either $0.28 \mu \mathrm{M} \mathrm{PGI}_{2}$ or $2 \mathrm{U}$ of thrombin for an additional $10 \mathrm{~min}$ at $37^{\circ} \mathrm{C}$. Data are presented as mean $\pm S E M$ of triplicate samples.

It should be emphasized that marked elevations in cyclic AMP and inhibition of thrombin-stimulated $\mathrm{PGI}_{2}$ biosynthesis were observed only when the phosphodiesterase was inhibited.

To assess the possible correlation between cyclic AMP elevation and the inhibition of $\mathrm{PGI}_{2}$ biosynthesis, we measured cyclic AMP levels in endothelial cells exposed to either $\mathrm{PGI}_{2}$ or thrombin with or without 0.1 or $1.0 \mathrm{mM}$ MIX (Table III). Treatment of the monolayers with $0.1 \mathrm{mM}$ or $1.0 \mathrm{mM}$ MIX increased cyclic AMP levels two- and four-fold, respectively (Table III). $\mathrm{PGI}_{2}$ or thrombin gave small increases in cyclic AMP without MIX, but $0.1 \mathrm{mM}$ MIX potentiated the $\mathrm{PGI}_{2}$ response to an eight-fold increase, and the thrombin response to a fourfold increase. In the presence of 1.0

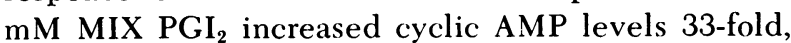
and thrombin 12-fold (Table III).

\section{DISCUSSION}

The observation that endothelial cells can synthesize $\mathrm{PGI}_{2}$ from either endogenous or exogenous endoperoxide $\mathrm{PGH}_{2}$ or arachidonic acid $(6,7)$ has generated a great deal of research concerning endothelial cellplatelet interactions. The thrust of the work has been to assess the influence of $\mathrm{PGI}_{2}$ produced by the endothelium on platelet aggregation and/or adhesion (5-10), but the possible effects of endogenously produced $\mathrm{PGI}_{2}$ on endothelial cell physiology per se have not as yet been explored.
Since $\mathrm{PGI}_{2}$ is a potent stimulator of adenylate cyclase in a variety of cell types $(10-12)$ we felt it was important to assess the influence of $\mathrm{PGI}_{2}$ on endothelial cell adenylate cyclase as well. $\mathrm{PGI}_{2}$ proved to be a potent stimulator of endothelial cell cyclic AMP accumulation when the cyclic AMP phosphodiesterase was inhibited. This dependence on phosphodiesterase inhibition contrasts sharply with the observed potency in other cultured cell lines $(10,12)$, but we have previously observed an analogous high level of cyclic AMP phosphodiesterase activity in isolated arterial rings (13). The control of endothelial cell sensitivity to $\mathrm{PGI}_{2}$ may be indirectly regulated through the phosphodiesterase, and any agent that suppresses phosphodiesterase activity would enhance the $\mathrm{PGI}_{2}$ response.

In addition to $\mathrm{PGI}_{2}$, exogenously added $\mathrm{PGH}_{2}$ was also readily converted to $\mathrm{PGI}_{2}$ by the endothelial cells resulting in an increase in endothelial cyclic AMP levels. The $\mathrm{PGI}_{2}$ dependence of the $\mathrm{PGH}_{2}$ response was evident by the ability of the prostacyclin synthetase inhibitors 12-HPETE or azo analog I to inhibit most of the $\mathrm{PGH}_{2}$ response. Complete inhibition of the $\mathrm{PGH}_{2}$ response is probably not attainable because considerable amounts of $\mathrm{PGE}_{2}$ are synthesized from $\mathrm{PGH}_{2}$ when the $\mathrm{PGI}_{2}$ synthetase is blocked, and $\mathrm{PGE}_{2}$ itself is a weak stimulator of cyclic AMP accumulation. The inhibition of the $\mathrm{PGI}_{2}$ synthetase by 12HPETE is potentially of in vivo significance. Since 12-HPETE is produced by the platelet $(28,29)$, it is possible that platelets interacting with the endothelium could inhibit $\mathrm{PGI}_{2}$ biosynthesis by producing 12 HPETE. Interestingly, aspirin treatment of platelets could exacerbate any 12-HPETE inhibition by shunting arachidonic acid toward the platelet lipoxygenase.

Besides prostaglandins, endothelial cell cyclic AMP levels can also be elevated by isoproterenol, but the $\beta$-adrenergic stimulation does not approach the magnitude of the $\mathrm{PGI}_{2}$ response.

The direct assay of adenylate cyclase activity in endothelial cell homogenates was not as successful as measurement of cyclic AMP levels in monolayers. The stimulations by both prostaglandins and isoproterenol were quite small, but correlate qualitatively with the data obtained in intact cells. The problem of loss of hormone responsive adenylate cyclase during cell processing is not a new one, but appears to be particularly troublesome in endothelial cells.

Our direct measurements of 6-keto-PGF ${ }_{1 \alpha}$ levels in thrombin-stimulated endothelial cells supports the work of Weksler et al. (27) that showed thrombin stimulation of $\mathrm{PGI}_{2}$ biosynthesis. In addition, we observed that when the phosphodiesterase was inhibited, agents that elevated cyclic AMP levels also attenuated thrombin-stimulated $\mathbf{P G I}_{2}$ biosynthesis. Our data showed that the phosphodiesterase inhibitor MIX at 1.0 
$\mathrm{mM}$ can also inhibit thrombin-stimulated $\mathrm{PGI}_{2}$ biosynthesis. These data at first were somewhat confusing because $1.0 \mathrm{mM}$ MIX alone did not markedly elevate cyclic AMP levels. However, these data are quite consistent with the other data because a combination of $1.0 \mathrm{mM}$ MIX and thrombin elevated cyclic AMP levels 12-fold due to the $\mathrm{PGI}_{2}$ biosynthesized in response to thrombin (Tables II and III). Subsequent experiments have shown that either $1 \mathrm{mM}$ aspirin or $10 \mu \mathrm{M}$ indomethacin completely inhibit thrombin-stimulated cyclic AMP accumulation.

The finding that $\mathrm{PGI}_{2}$ was a potent stimulator of cyclic AMP accumulation in endothelial cells suggests that once $\mathrm{PGI}_{2}$ is produced it can have at least two actions. Newly synthesized $\mathbf{P G I}_{2}$ can interact with platelets, elevate cyclic AMP, and inhibit aggregation. Concurrently, it would be capable of elevating endothelial cell cyclic AMP levels and attenuating further $\mathrm{PGI}_{2}$ biosynthesis. This type of feedback inhibition would have to be highly sensitive to small increases in cyclic AMP, because without phosphodiesterase inhibition, there was little increase in cyclic AMP. In the human platelet, $\mathrm{PGI}_{2}$ inhibits platelet aggregation in the nanomolar range by elevating cyclic AMP $10-15 \mathrm{pmol} / 10^{9}$ platelets above basal levels, but the platelet is capable of making 6,000-7,000 pmol of cyclic AMP in response to $2.8 \mu \mathrm{M} \mathrm{PGI} \mathrm{PG}_{2}(30)$. Clearly most of the potential responsiveness to $\mathrm{PGI}_{2}$ in the platelet is not expressed. An analogous situation may exist in the endothelial cell.

The precise physiological significance of the $\mathrm{PGI}_{2}$ elevation of endothelial cell cyclic AMP levels and subsequent inhibition of $\mathrm{PGI}_{2}$ biosynthesis cannot be established by this paper. Previous work has shown that by elevating cyclic AMP, $\mathrm{PGI}_{2}$ can inhibit arachidonic acid transformation in the human platelet (31). The inhibition by cyclic AMP was at the level of the phospholipase. Our data are consistent with a phospholipase inhibition, but do not rule out inhibition at the level of the cyclooxygenase or the $\mathrm{PGI}_{2}$ synthetase.

We are presently studying $\mathrm{PGI}_{2}$ biosynthesis in endothelial cells to establish exactly at what level(s) biosynthesis is interrupted. Regardless of the exact point of control, it is clear that endothelial biosynthesis of $\mathrm{PGI}_{2}$ is not a passive phenomenon. The cells are responsive to this compound as well.

\section{REFERENCES}

1. Moncada, S., R. J. Gryglewski, B. Bunting, and J. R. Vane. 1976. An enzyme isolated from arteries transforms prostaglandin endoperoxides to an unstable substance that inhibits platelet aggregation. Nature (Lond.). 263: 663-665.

2. Johnson, R. A., D. R. Morton, J. H. Kinner, R. R. Gorman, J. C. McGuire, F. F. Sun, N. Whittaker, S. Bunting, J. Sal- mon, S. Moncada, and J. R. Vane. 1976. The chemical structure of prostaglandin X (prostacyclin). Prostaglandins. 12: 915-928.

3. Gorman, R. R., S. Bunting, and O. V. Miller. 1977. Modulation of human platelet adenylate cyclase by prostacyclin (PGX). Prostaglandins. 13: 377-388.

4. Tateson, J., S. Moncada, and J. R. Vane. 1977. Effects of prostacyclin (PGX) on cyclic AMP concentrations in human platelets. Prostaglandins. 13: 389-399.

5. Moncada, S., E. A. Higgs, and J. R. Vane. 1977. Human arterial and venous tissues generate prostacyclin (prostaglandin $\mathrm{X}$ ), a potent inhibitor of platelet aggregation. Lancet. I: 18-21.

6. Weksler, B. B., A. J. Marcus, and E. A. Jaffe. 1977. Synthesis of prostaglandin $I_{2}$ (prostacyclin) by cultured human and bovine endothelial cells. Proc. Natl. Acad. Sci. U. S. A. 74: 3922-3926.

7. Marcus, A. J., B. B. Weksler, and E. A. Jaffe. 1978. Enzymatic conversion of prostaglandin endoperoxide $\mathrm{H}_{2}$ and arachidonic acid to prostacyclin by cultured human endothelial cells. J. Biol. Chem. 253: 7138-7141.

8. Gorman, R. R. 1979. Modulation of human platelet function by prostacyclin and thromboxane $\mathrm{A}_{2}$. Fed. Proc. 38: 79-85.

9. Moncada, S., and J. R. Vane. 1979. Prostacyclin in perspective. In Prostacyclin. J. R. Vane and S. Bergstrom, editors. Raven Press, New York. 5-16.

10. Gorman, R. R., R. D. Hamilton, and N. K. Hopkins. 1979. Stimulation of human foreskin fibroblast adenosine $3^{\prime}, 5^{\prime}$ cyclic monophosphate levels by prostacyclin $\left(\mathrm{PGI}_{2}\right)$. J. Biol. Chem. 254: 1671-1676.

11. Kather, H., and B. Simon. 1979. Effects of some naturally occurring prostaglandins of the D, E, and I-type and synthetic analogues on adenylate cyclase of human fat cell ghosts. Res. Exp. Med. 176: 25-29.

12. Ortmann, R. 1978. Effect of $\mathrm{PGI}_{2}$ and stable endoperoxide analogues on cyclic nucleotide levels in clonal cell lines of CNS origin. FEBS (Fed. Eur. Biochem. Soc.) Lett. 90: 348-352.

13. Miller, O. V., J. W. Aiken, D. P. Hemker, R. J. Shebuski, and R. R. Gorman. 1979. Prostacyclin stimulation of dog arterial cyclic AMP levels. Prostaglandins. 18: 915-925.

14. Gorman, R. R., F. F. Sun, O. V. Miller, and R. A. Johnson. 1977. Prostaglandins $H_{1}$ and $H_{2}$. Convenient biochemical synthesis and isolation. Further biological and spectroscopic characterization. Prostaglandins. 13: 1043-1053.

15. Nugteren, D. H. 1975. Arachidonate lipoxygenase in blood platelets. Biochim. Biophys. Acta. 380: 299-307.

16. Steiner, A. L., C. W. Parker, and D. M. Kipnis. 1972. Radioimmunoassay for cyclic nucleotides. I. Preparation of antibodies and iodinated cyclic nucleotides. J. Biol. Chem. 247: 1106-1113.

17. Harper, J. F., and G. Brooker. 1975. Femtomole sensitive radioimmunoassay for cyclic AMP and cyclic GMP after $2^{\prime} 0$ acetylation by acetic anhydride in aqueous solution. J. Cyclic Nucleotide Res. 1: 207-218.

18. Dray, F., K. Gerozissis, B. Kouznetzova, and S. Mamas, P. Pradelles, and G. Trugnan. 1980. New Approaches to the RIA of Prostaglandins and Related Compounds Using Iodinated Tracers. Adv. Prostaglandin Thromboxane Res. 6: 167-185.

19. Rodbell, M. 1967. Metabolism of isolated fat cells. V. Preparation of "ghosts" and their properties: adenylcyclase and other enzymes. J. Biol. Chem. 242: 5744-5752.

20. Salomon, Y., C. Londos, and M. Rodbell. 1974. A highly sensitive adenylate cyclase assay. Anal. Biochem. 58: 541-548. 
21. Lowry, O. H., N. Y. Rosebrough, A. L. Farr, and R. J. Randall. 1951. Protein measurement with the Folin phenol reagent. J. Biol. Chem. 193: 265-275.

22. Jaffe, E. A., R. L. Nachman, C. G. Becker, and C. R. Minick. 1973. Culture of human endothelial cells derived from umbilical cord veins. J. Clin. Invest. 52: 2745-2756.

23. Weibel, E. R., and G. E. Palade. 1964. New cytoplasmic components in arterial endothelia. J. Cell Biol. 23: 101-110.

24. Jaffe, E. A., L. W. Hoyer, and R. L. Nachman. 1974. Synthesis of vanWillebrand factor by cultured human endothelial cells. Proc. Natl. Acad.Sci.U.S.A. 71: 1906-1909.

25. Jaffe, E. A., L. W. Hoyer, and R. L. Nachman. 1973. Synthesis of antihemophilic factor antigen by cultured human endothelial cells. J. Clin. Invest. 52: 2757-2764.

26. Buonassisi, V., and J. G. Venter. 1976. Hormone and neurotransmitter receptors in an established vascular endothelial cell line. Proc. Natl. Acad. Sci. U. S. A. 73: 1612-1616.
27. Weksler, B., C. W. Ley, and E. A. Jaffe. 1978. Stimulation of endothelial cell prostacyclin production by thrombin, trypsin, and the ionophore A23187. J. Clin. Invest. 62: 923-930.

28. Hamberg, M., J. Svensson, and B. Samuelsson. 1974. Prostaglandin endoperoxides. A new concept concerning the mode of action and release of prostaglandins. Proc. Natl. Acad. Sci. U. S. A. 71: 3824-3828.

29. Nugteren, D. H. 1975. Arachidonate lipoxygenase in blood platelets. Biochim. Biophys. Acta 380: 299-307.

30. Miller, O. V., J. W. Aiken, R. J. Shebuski, and R. R. Gorman. 1980. 6-Keto-Prostaglandin $\mathrm{E}_{1}$ is not equipotent to prostacyclin $\left(\mathrm{PGI}_{2}\right)$ as an antiaggregatory agent. Prostaglandins. 20: 391-400.

31. Minkes, M., N. Stanford, M.-Y. Chi, G. J. Roth, A. Raz, P. Needleman, and P. W. Majerus. 1977. Cyclic adenosine $3^{\prime}, 5^{\prime}$-monophosphate inhibits the availability of arachidonate to prostaglandin synthetase in human platelet suspensions. J. Clin. Invest. 59: 449-454. 